DOI https://doi.org/10.30525/978-9934-26-073-5-2-55

\title{
ВЕРБАЛЬНИЙ І ВІЗУАЛЬНИЙ МОДУСИ ПЕДАГОГІЧНОЇ РИТОРИКИ
}

\author{
Жаркова P. С. \\ кандидат філологічних наук, \\ доцент кафедри початкової та дошкільної освіти \\ Львівського національного університету імені Івана Франка
}

\author{
Крохмальна Г. I. \\ кандидат філологічних наук, \\ дочент кафедри початкової та дошкільної освіти \\ Львівського національного університету імені Івана Франка \\ м. Львів, Украӥна
}

Важливість риторичної майстерності важко перебільшити, оскільки особистісний розвиток тісно пов'язаний з мистецтвом самовираження, вмінням презентувати свої переконання. Чіткість, логічність суджень, аргументованість, послідовність викладу думок, доцільність і точність мовлення, володіння етичними принципами міжкультурної комунікації усе це ознаки мовлення сучасної ерудованої людини. Відтак можна розглядати риторику як «суцільний пошук вільного простору для самовияву» [6, с. 12], відповідно до законів античної філософії, де «мовна комунікація за риторичною логікою і риторичними правилами виявляється причетною до самого життя грою смислів, стає розумною здійсненністю цього життя» [6, с. 13].

Зв'язок естетичного і прагматичного виявляється саме у риторичних вміннях мовця, у доборі тих мовних одиниць, які можуть зробити висловлене цілісним і ціннісним. Тому слід розглядати риторичну культуру в багатьох аспектах: особистісному, професійному, суспільноісторичному тощо. О. Синчак зауважує, що наше щодення поступово заполонило поняття «риторичності», яке «виявляється цінним саме завдяки прихованому в ньому евристичному потенціалу - провадити до усвідомлення, що риторичні механізми, по-перше, «вшито» в саму мову як іiі універсальну властивість (звідси черпають наснагу порівняльна риторика та риторична критика), а по-друге, саме вони творять тканину тексту (неориторика, загальна риторика, риторична прагматика)» [8, c. 34-35]. 
Чимало дослідників розглядали питання мовної комунікації (Ф. Бацевич, П. Донець, Г. Мацюк, Г. Онуфрієнко, В. Паращук, О. Селіванова, О. Семенюк), риторичної майстерності (С. Абрамович, Н. Колотілова), мовної культури (Н. Бабич, Т. Гриценко, М. Пентилюк, О. Пономарів, Я. Радевич-Винницький), роль слова у роботі вчителя школи й викладача ЗВО (Н. Голуб, І. Дроздова, А. Капська, К. Климова, С. Караман, О. Караман, Г. Клочек, А. Курінна, А. Нікітіна, С. Мартиненко, Л. Мацько, Ю. Пінчук, Ю. Романенко, Г. Сагач). На думку науковців, педагогічна риторика - це «міжгалузева дисципліна, що увібрала в себе сукупність міжпредметних аспектів» [5, с. 11], предметом вивчення якої $є$ «система принципів, прийомів, умов, моделей ефективного риторичного навчання вчителя як мовної особистості елітарного типу» [5, с. 12].

О. Корчова наголошує, що «через слово і засобами слова майбутні педагоги [...] формують себе як культуромовну особистість - носія унікального світогляду в полікультурному світі» [4, с. 117]. Актуальним $\epsilon$ соціокультурний підхід, адже «мовно-мовленнєві явища в риториці доцільно розглядати 3 позиції риторичних моделей комунікативної діяльності, що уможливить органічну інкорпорацію суб'єкта до системи сучасної йому культури, забезпечить його самовиявлення та самоідентифікацію» [4, с. 118]. Така метафорична інкорпорація можлива завдяки пізнанню світової класики, мистецтва, літературних та фольклорних творів, що впливають на ментальний i психоемоційний світ людини.

В останні десятиліття активізується цифрова риторика як спосіб передачі інформації через медіа. Масштабний розвиток IКТ і глобалізаційні процеси трансформували риторику вербального у риторику візуального (М. Джонсон, С. Застровська, Н. Коваленко, Ю. Лапшина, Дж. Лакофф, Л. Масімова, Т. Семенюк, Т. Храбан, М. Яцимірська). Одним із перших про «риторику образу» заговорив у 60-х рр. XX ст. Р. Барт, аналізуючи рекламний продукт [1]. Наприкінці 90-х поч. 2000-х рр. поглиблюються студії 3 візуальної комунікації та кіберкультури [9], інтернет-комунікації [10], методики візуальної презентації (інфографіка) [2] тощо. Переконання, що усе можна (по)казати (обираючи відповідні способи та засоби) опановує нашу реальність. Як стверджує М. Данесі [11], існує чимало різновидів візуальних текстів, які допомагає нам відчитувати семіотика. «Силу малюнка» (сенси якого закодовані через метафору та алюзію) можна використовувати для впливу і переконання, для мотивації та маніпуляції, тому візуальні меседжі поширені у науці і техніці, психології, антропології, маркетингу, графічному дизайні, рекламі. Візуальна риторика показує нам, як можна декодувати структуру образу, 
«починаючи від простої ідентифікації (називання того, що бачимо) до складної інтерпретації на контекстуальному, метафоричному та філософському рівнях» [11].

Застосування концепцій візуальної риторики у роботі педагога передбачає не лише показ малюнків, фотографій, схем, діаграм, мап, таблиць як елементів наочності. Йдеться передусім про те, що візуальний контент, за словами дослідниці риторичної теорії і критики С.-К. Фосс, «трансформує саму риторичну теорію» [12, р. 304], відкриваючи ій «можливості для більш релевантних, інклюзивних та цілісних поглядів на сучасне використання символів» [12, р. 313]. Адже досвід(и) «візуального мислення» [14] (клік-мислення, кліп-мислення та інші визначення сучасного способу (c)прийняття інформаційного потоку) модифікували вербальний дискурс у «візуальну мову» глобальної комунікації XXI ст. Щодо співвідношення вербального й візуального у навчанні, то Г. Клочек пропонує послуговуватися поняттям «риторика слайду» [3, с. 156], застерігаючи, що «мультимедійні технології [...] відвернули увагу від мистецтва педагогічного слова» [3, с. 152], тому відбувається неминуча втрата людиною свого "риторичного потенціалу» [3, с. 153]. Усе частіше живе слово замінюється візуальним рядом: увага авдиторії деконцентрується, вона повинна і слухати промовця, і читати/дивитися на екрані форсований рух текстів/малюнків.

Візуалізація тепер є цінним атрибутом освіти: технології візуалізації навчального матеріалу (Д. Безуглий), використання технологій візуалізації для інтенсифікації навчального процесу (Л. Білоусова), візуальна мова ілюстрації як засіб комунікації (Т. Лук'янова), кіновізуальний контекст в освітніх практиках (А. Маргулов) тощо. Зокрема, О. Семеніхіна та Д. Безуглий пропонують використовувати термін «візуалізація знань», адже «майбутній вчитель, оперуючи графічними образами, має бути спроможним так унаочнити певний факт, щоб продемонструвати закономірності, властивості, характеристичні особливості об'єкта» [7, с. 53]. Але тільки «дидактично вивірене використання візуальних образів у навчанні може перетворити наочність з допоміжного засобу, який лише ілюструє, у когнітивний інструмент навчання» [7, с. 53].

Отже, «візуальна мова» [13] наповнила наше щодення новими сенсами. Значимим є синтез вербального та візуального у сфері міжкультурної комунікації, зокрема, у педагогічній взаємодії. Педагогічна риторика активно опановує дієві інструменти візуального контенту, намагаючись балансувати між словесними та наочно-образними методами навчання. Лише комплексне їх поєднання зробить освітній процес якісним і гармонійним. 


\section{Література:}

1. Барт Р. Избранные работы: Семиотика: Поэтика: пер. с фр. М.: Прогресс, 1989, 616 c.

2. Каїро А. Функціональне мистецтво: вступ до інфографіки та візуалізації: пер. $з$ англ. Львів: Видавництво УКУ, 2017. 350 с.

3. Клочек Г. Зі студій про літературну освіту. Тернопіль: Навчальна книга - Богдан, 2013. 192 с.

4. Корчова О. Соціокультурний підхід до вивчення риторики в педагогічному закладі вищої освіти // Інноваційна педагогіка, 2019. Вип. 10. T. 2. C. $117-120$.

5. Педагогічна риторика: історія, теорія, практика: монографія: [О.А. Кучерук, Н. Б. Голуб, О. М. Горошкіна, С. О. Караман та ін.]. Київ: КНТ, 2016. 258 с.

6. Сватко Ю. І. Народження риторики з духу філософії, або деякі наслідки античного філософствування «з людським обличчям» // Магістеріум. Історико-філософські студії, 2014. Вип. 55. С. 3-15.

7. Семеніхіна О., Безуглий Д. Необхідність формування у вчителів умінь візуалізувати предметні знання як провідна стратегія розвитку освіти в Україні // Гірська школа Українських Карпат, 2017. №16. С. 51-53.

8. Синчак О. Риторичність: повернення риторики в нурт філології // Наукові записки УКУ. Серія «Філологія». Львів, 2020. Вип. 1. С. 13-36.

9. Bell D. Introduction to Cyberculture. London; New York: Routledge, 2004. $288 \mathrm{p}$.

10. Crystal D. Language and Internet. Cambridge: Cambridge University Press, 2006. $316 \mathrm{p}$.

11. Danesi M. Visual Rhetoric and Semiotic // Oxford Research Encyclopedia of Communication, 2017. Електронний ресурс. Режим доступу: https://oxfordre.com/communication/view/10.1093/acrefore/9780 190228613.001.0001/acrefore-9780190228613-e-43\#acrefore-9780190228 613-e-43-div1-1

12. Foss S.-K. Framing the Study of Visual Rhetoric: Toward a Transformation of Rhetorical Theory // Defining Visual Rhetorics: ed. by Charles A. Hill and M. Helmers. Mahwah, NJ: Lawrence Erlbaum, 2004. P. 303-313.

13. Horn R.-E. Visual Language: Global Communication for the 21st Century. Bainbridge Island, WA: MacroVU, Inc., 1998. 270 p.

14. McKim R.-H. Experiences in Visual Thinking. Monterey: Brooks/Cole, 1980. 183 p. 